\title{
SIMULASI SEBAGAI PENYEBAB CACAT KONSENSUS
}

\author{
Oleh Fransiskus Siku Jata
}

\begin{abstract}
Abstrak
Judul tulisan ini ialah Simulasi Sebagai Penyebab Cacat Konsensus atau Kesepakatan Nikah. Topik ini diangkat karena dalam memproses perkara anulasi perkawinan, simulasi atau kepurapuraan sering ditetapkan sebagai pokok sengketa (caput nulitatis). Dalam Kitab Hukum Kanonik 1983, simulasi sebagai cacat kesepakatan nikah ada dalam Kanon 1101. Penulis membahas simulasi menurut Kan. 1101 dengan maksud agar pembaca memahami inti hakekat simulasi atau kepura-puraan sebagaimana dimaksudkan oleh kanon tersebut.

Metode penulisan yang digunakan ialah penelitian kepustakaan. Penulis secara khusus menggali tulisan dan informasi tentang simulasi dari sisi hukum kanonik Gereja Katolik. Karena itu bukubuku sumber yang digunakan umumnya adalah karya para yurist. Simulasi berarti adanya ketidaksesuaian antara kata-kata atau isyarat yang dinyatakan dalam merayakan perkawinan dengan kesepakatan batin dalam hati. Menurut Kan. 1101, ada simulasi total (simulatio totalis) dan simulasi sebagian (simulatio partialis). Simulasi terjadi ketika salah satu pihak atau kedua belah pihak dengan positif kemauannya mengecualikan perkawinan itu sendiri (simulatio totalis), atau salah satu unsur hakiki perkawinan, atau salah satu sifat hakiki perkawinan (simulatio partialis) pada saat perkawinan dilangsungkan. Dan adanya simulasi dapat menjadi dasar untuk anulasi perkawinan melalui Tribunal Gerejawi.
\end{abstract}

Kata-kata kunci: Perkawinan, konsensus, simulasi, total, parsial.

\section{PENDAHULUAN}

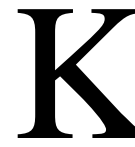

itab Hukum Kanonik 1983 yang dipromulgasikan oleh Paus Yohanes Paulus II pada tanggal 25 Januari 1983 menyatakan bahwa syarat-syarat untuk sahnya sebuah (kann.1073-1094); kedua, harus adanya konsensus atau kesepakatan perkawinan (kann. 10951103); dan ketiga, harus dirayakan dengan tata peneguhan perayaan perkawinan atau forma canonica (kann. 1108-1123).

Syarat kedua demi sahnya sebuah perkawinan adalah adanya konsensus. Konsensus atau kesepakatan perkawinan menurut Kan. $1057 \S 2$ adalah "tindakan kehendak dengan mana seorang laki-laki dan seorang perempuan saling menyerahkan diri dan saling menerima untuk membentuk perkawinan dengan perjanjian yang tak dapat ditarik kembali." Pernyataan kanon ini menunjuk dua objek kesepakatan nikah, yakni pertama: adanya tindakan saling menyerahkan diri dan saling menerima diri antara satu orang pria dan satu orang wanita. Objek ini merupakan kekhasan atau inti sari dari perkawinan (GS 49); dan obyek kedua yang merupakan konsekwensi logis dari objek pertama ialah untuk membentuk perkawinan. Dengan keterangan ini dapat ditegaskan bahwa konsensus atau kesepakatan adalah momen yang menciptakan perkawinan. Konsensus membuat suatu perkawinan menjadi ada. Dengan mengucapkan janji atau konsensus, perkawinan itu ada, dan hidup berkeluarga itu dimulai dan berlangsung sepanjang hidup mempelai. 
Jika objek dari konsensus atau kesepakatan adalah perkawinan, pertanyaannya, apa saja unsur-unsur hakiki dan sifat-sifat hakiki dari perkawinan? Menurut Kanon $1055 \S 1$, unsur-unsur hakiki perkawinan ialah kesejahteraan suami istri serta kelahiran dan pendidikan anak. Dan menurut Kanon 1056 ciri-ciri atau sifat-sifat hakiki perkawinan ialah unitas (kesatuan) dan indissolubilitas (sifat tak dapat diputuskan) serta memperoleh martabat sakramental (bagi perkawinan yang terjadi antara dua orang yang telah dibaptis).

Konsensus atau kesepakatan yang diteguhkan bisa saja cacat atau tidak sah. Kitab Hukum Kanonik 1983, Kann. 1095-1103 menunjuk beberapa kemungkinan terjadinya defectus consensus (cacat kesepakatan perkawinan). Faktor-faktor penyebab cacat kesepakatan perkawinan ialah ketidakmampuan psikologis (Kan. 1095), tak ada pengetahuan yang cukup mengenai hakekat perkawinan (Kan. 1096), kekeliruan mengenai pribadi (Kan. 1097), penipuan (Kan. 1098), kekeliruan mengenai sifat perkawinan dan martabat sakramental perkawinan (Kan. 1099), simulasi atau kepura-puraan (Kan. 1101), konsensus bersyarat (Kan. 1102), serta paksaan dan ketakutan (Kan. 1103).

Tribunal Perkawinan Keuskupan Agung Ende dalam melaksanakan tugas membantu menyelesaikan permasalahan-permasalahan perkawinan para suami istri, telah menyelenggarakan sidang-sidang tribunal untuk anulasi perkawinan. Dari kasus-kasus perkawinan yang dilimpahkan ke meja tribunal (tahun 2018-2020), ${ }^{1}$ yang selanjutnya diratifikasi dan dianulasi, ditemukan bahwa kanon 1101 sering ditetapkan sebagai pokok sengketa (caput nulitatis) perkawinan. Atas alasan itu penulis mengangkat topik tentang simulasi menurut kanon 1101. Maksudnya ialah agar pembaca memahami inti hakekat simulasi atau kepura-puraan sebagaimana dimaksudkan oleh kanon tersebut.

Dalam keseluruhan Kitab Hukum Kanonik 1983, Kan. 1101 berada dalam tema pembahasan tentang Tugas Mengajar Gereja (buku IV), pada bagian Sakramen (bagian I), dalam judul tentang Perkawinan (judul VII), dan pada uraian tentang Kesepakatan Nikah atau konsensus (bab IV). Kanon 1101 merupakan salah satu kanon yang berbicara tentang hal yang dapat menyebabkan konsensus atau kesepakatan nikah yang diteguhkan bisa saja tidak sah atau cacat. Dan setiap perkawinan yang mengalami cacat konsensus, dengan sendirinya menjadi tidak sah, dan cacat konsensus serentak menjadi dasar hukum untuk proses anulasi atau pembatalan perkawinan. $^{2}$

\section{Formulasi Kanon 1101 dan Hakekat Simulasi}

Menurut Kitab Hukum Kanonik 1983, rumusan Kanon 1101 adalah sebagai berikut: $\S 1$. "Kesepakatan batin dalam hati diandaikan sesuai dengan kata-kata atau isyarat yang dinyatakan dalam merayakan perkawinan". § 2. "Tetapi bila salah satu atau kedua pihak dengan tindakan positif kemauannya mengecualikan perkawinan itu sendiri, atau salah satu unsur hakiki perkawinan, atau salah satu proprietas perkawinan yang hakiki, ia melangsungkan perkawinan dengan tidak sah".

\footnotetext{
${ }^{1}$ Bdk. Putusan-Putusan Tribunal KAE, 2018-2020.

2 Don Wea S.Turu, Pencerahan Yuridis, Problematika dan Pemecahan Berdasarkan Kitab Hukum Kanonik 1983, (Yogyakarta: Bajawa Press, 2014), hlm. 45.
} 
Hal pertama yang ditegaskan oleh Kanon $1101 \S 1$ ialah adanya pengandaian kesesuaian antara kata hati dengan kata-kata atau isyarat yang dinyatakan dalam merayakan perkawinan. Ini adalah pengandaian yuridis yang memberikan perlindungan hukum atas setiap perkawinan yang dirayakan. Selama tidak ada gugatan atas pengandaian yuridis ini, maka setiap perkawinan adalah sah.

Hal kedua yang ditegaskan oleh Kanon 1101 \& 2 ialah adanya kemungkinan ketidaksesuaian antara kata hati dengan kata-kata atau isyarat yang dinyatakan dalam perkawinan membuat perkawinan dilangsungkan dengan tidak sah. Ini merupakan dugaan adanya simulasi atau kepura-puraan yang membuat perkawinan tidak sah. Simulasi dapat dilakukan entah oleh "salah satu pihak" atau oleh "kedua pihak", yang dengan "tindakan positif kemauan" mengecualikan "perkawinan itu sendiri" atau "salah satu unsur hakiki perkawinan" atau "salah satu proprietas/sifat hakiki perkawinan".

Apakah yang dimaksudkan dengan simulasi sebagai penyebab cacat konsensus atau kesepakatan perkawinan? Simulasi berarti ketidaksesuaian antara pernyataan lahiriah (kata-kata dan isyarat) dengan kehendak sebenarnya di dalam batin. Dalam hubungan dengan kesepakatan perkawinan, Gereja mengandaikan bahwa kehendak yang dinyatakan atau nampak dalam kata dan perbuatan sungguh-sungguh merupakan pengungkapan atau perwujudan kehendak batiniah. Jika hal yang diandaikan Gereja tersebut tidak ada, maka terjadilah apa yang disebut dengan simulasi atau kepura-puraan atau kesemuan. Ketidaksesuaian ini membuat kesepakatan nikah itu cacat. Dengan demikian perkawinan tersebut dinyatakan tidak sah. Pernyataan bahwa sebuah perkawinan tidak sah karena adanya simulasi dan dinyatakan batal harus melalui proses peradilan Tribunal Gerejawi. ${ }^{3}$

Tolok ukur lain yang perlu dimengerti secara tepat adalah bahwa simulasi terjadi jika salah satu atau kedua belah pihak dengan positif kemauannya mengecualikan perkawinan itu sendiri, atau salah satu unsur hakiki perkawinan, atau salah satu sifat hakiki perkawinan pada saat perkawinan dilangsungkan. Mengecualikan perkawinan itu sendiri, atau salah satu unsur hakiki perkawinan, atau salah satu sifat hakiki perkawinan tidak selalu berarti hal itu terjadi karena niat buruk. Hal yang mau ditegaskan dan ditekankan ialah bahwa simulasi sesungguhnya adalah fakta kesenjangan antara apa yang diungkapkan dengan apa yang dikehendaki nyata dalam pribadi seseorang. Yang bersangkutan dengan positif kemauannya mengecualikan entah perkawinan itu sendiri, atau salah satu unsur hakiki perkawinan, atau salah satu sifat hakiki perkawinan, namun secara formal ia melangsungkan perkawinan dengan memberikan kesepakatan perkawinannya. ${ }^{4}$

\section{Unsur-Unsur Pembentuk Simulasi}

Kitab Hukum Kanonik tidak menunjukkan secara eksplisit unsur-unsur yang membentuk simulasi sehingga kesepakatan perkawinan dapat dinyatakan catat atau tidak sah. Hal-hal yang dapat membentuk simulasi itu hanya dapat disimpulkan dari Kan. 1057 § 2 dan Kanon $1101 \S 2$.

\footnotetext{
${ }^{3}$ Benyamin Yosef Bria, Pastoral Perkawinan Gereja Katolik Menurut Kitab Hukum Kanonik 1983 Kajian dan Penerapannya, (Yogyakarta: Yayasan Pustaka Nusatama, 2007), hlm. 69.
}

\footnotetext{
${ }^{4}$ Moses Komela Avan, Kebatalan Perkawinan, Pelayanan Hukum Gereja Dalam Proses Menyatakan Kebatalan
} Perkawinan, (Yogyakarta: Kanisius, 2014), hlm. 125. 
Kan. 1057 § 2 menyatakan bahwa konsensus atau kesepakatan adalah tindakan kehendak, dan Kanon $1101 \S 2$ menyatakan bahwa simulasi sebagai kesepakatan yang palsu atau tidak sah haruslah merupakan tindakan positif dari kehendak seseorang. Berdasarkan ketentuan-ketentuan yang terdapat dalam dua (2) kanon ini, maka dapatlah ditegaskan bahwa unsur-unsur pembentuk simulasi terdiri dari kehendak (voluntas), tindakan (actus), dan positif (positivus).

\subsection{Kehendak}

Unsur pertama dan utama dari simulasi adalah kehendak seseorang. Kehendak adalah penyebab dan penggerak pertama, sumber utama dari simulasi yang mengeksklusikan objek perkawinan. Kehendak yang dimaksud di sini merupakan intensionalitas dari kemauan, yang berbeda dengan akal budi, karena akal budi tidak bisa menjadi sumber langsung dan efektif untuk bersimulasi. Tindakan kehendak yang sadar dan bebas harus dibedakan dari ide, pendapat, keyakinan, atau wacana; juga harus dibedakan dari kerinduan, afeksi, sentimen, dan anggapan. Semua unsur ini bisa mendorong orang untuk berpikir dan menimbang dalam rangka mengambil keputusan, namun unsur-unsur tersebut tidaklah identik dan tidak harus terwujud secara otomatis dalam tindakan kehendak positif. Dengan kata lain sumber pertama dan utama dari simulasi adalah kehendak, bukan akal budi atau pengetahuan intelektual manusia. Karena itu, jika tidak ada kehendak atau intensionalitas dari kemauan, maka simulasi tidak ada. ${ }^{5}$

Dalam kesepakatan nikah yang sah, kehendak seseorang mengasumsi seluruh masa depan perkawinannya dalam tindakan "menyepakati di sini dan saat ini", dan kemudian mengembannya dalam kehidupan perkawinan yang riil. Lain halnya dengan kesepakatan nikah yang tidak sah. Dalam kesepakatan nikah yang tidak sah, seseorang menghendaki perkawinan "saat ini", namun sekaligus mereservasi (mengeksklusi) di dalam tindakannya salah satu aspek hakiki dari perkawinan. ${ }^{6}$

Simulasi terjadi ketika ada ketidaksesuaian antara pernyataan verbal (yang memberi kesan lahiriah kepada pasangan atau saksi bahwa ada kehendak untuk menikah) dengan kehendak positif dalam batin (yang mengeksklusi perkawinan itu sendiri atau salah satu unsur hakiki atau sifat hakiki perkawinan). Hukum kanonik menganut teori hukum kehendak, bukan teori pernyataan yuridis. Untuk sahnya sebuah tindakan yuridis, hukum kanonik menuntut kesesuaian efektif antara isi kehendak dan isi pernyataan kehendak (pernyataan yuridis). Karena itu, simulasi terjadi bila ada ketidaksesuaian atau kebertolakbelakangan antara yang dikehendaki dengan yang dinyatakan. ${ }^{7}$

Dalam kehendak bersimulasi, intensi yang benar untuk menikah diganti dengan kehendak untuk sekadar melakukan perayaan nikah secara lahiriah. Sebagaimana kesepakatan yang sah mengandung hanya satu kehendak, yaitu kehendak yang benar dan integral untuk menikah; demikian pula dalam simulasi hanya ada satu kehendak yang sadar untuk melakukan simulasi, yakni dengan cara mengganti intensi yang benar dengan intensi yang bertentangan dengan pernikahan. Objek perkawinan yang seharusnya dikehendaki secara positif dalam kesepakatan yang benar diganti dengan objek lain yang bukan ikatan nikah, atau yang bertentangan dengan tujuan dan sifat-sifat hakiki dari perkawinan. Sebagai misal, seorang simulator secara sadar dan

\footnotetext{
${ }^{5}$ Alf. Catur Raharso, Kesepakatan Nikah Dalam Hukum Perkawinan Katolik, (Malang: Dioma, 2008), hlm. 252.

${ }^{6}$ Ibid.

${ }^{7}$ I Gusti Bagus Kusumawanta, Yurisprudensi Hukum Kanonik, (Yogyakarta: Alinea Baru, 2019), hlm. 33.
} 
positif menginginkan perkawinan, namun sekaligus dengan kebebasan melakukan relasi seksual dengan pria atau wanita lain selama hidup perkawinannya. ${ }^{8}$ Kehendak mengganti intensi yang benar yang mengeksklusi perkawinan atau salah satu unsur hakiki perkawinan dapat dibedakan atas empat (4) tipe. ${ }^{9}$

Pertama: Tidak adanya kehendak untuk menikah (intentio contrahendi). Yang dimaksudkan ialah pada waktu meneguhkan perkawinan, salah satu atau kedua pihak sama sekali tidak memiliki kehendak batin untuk bersatu dalam perkawinan. Satu-satunya yang dikehendaki ialah manifestasi eksternal dan seremonial belaka. Tidak adanya kehendak untuk menikah ini sungguh-sungguh disadari dan disengaja. Dengan itu para simulator memalsukan tanda lahiriah, dan dengan sengaja menggantikan intensi yang sebenarnya untuk menikah. Hal ini mengakibatkan eksklusi atau penolakan terhadap ikatan perkawinan itu sendiri.

Kedua: Adanya kehendak positif untuk melakukan kesepakatan yang bukan perkawinan atau yang bertentangan dengan perkawinan (intentio contrahendi non matrimonialis). Yang dimaksud ialah pada waktu meneguhkan perkawinan, salah satu atau kedua pihak memiliki paham perkawinan dan menghendaki perkawinan yang bertentangan dengan tujuan dan sifat hakiki perkawinan, sebagaimana dikehendaki oleh Sang Pencipta sejak semula dan dihiasi dengan hukum-hukumnya. Yang terjadi di sini bukanlah tidak ada pengetahuan yang benar tentang perkawinan, juga bukan kekeliruan substansial yang memengaruhi kehendak; melainkan eksklusi terjadi secara tidak langsung, karena satu-satunya tindakan positif kehendak bukanlah perkawinan yang secara objektif sesuai dengan tujuan dan sifat hakikinya, melainkan paham subjektif yang menggantikan paham yang benar tentang perkawinan.

Ketiga: Adanya kehendak positif untuk tidak menikah (intentio non contrahendi). Yang dimaksud ialah pada waktu meneguhkan perkawinan, salah satu atau kedua pihak memiliki kehendak positif, baik aktual maupun virtual yang tidak ditarik kembali, yang menolak secara langsung entah pribadi pasangannya sendiri, ikatan nikah dengan pasangannya, tujuan dan sifatsifat hakiki perkawinan serta hak dan kewajiban hakiki perkawinan. Objek langsung dan sengaja dari tindakan positif kehendak ialah tidak mau membangun perkawinan yang sejati.

Keempat: Adanya kehendak untuk tidak mengikatkan diri (intention non se obligandi). Yang terjadi di sini bukan simulasi dalam melakukan kesepakatan nikah, juga bukan penolakan terhadap perkawinan itu sendiri, atau salah satu unsur atau sifat hakiki dari perkawinan; melainkan salah satu atau kedua pihak tidak menghendaki daya wajib atau daya ikat yuridis dari perkawinan yang dilakukannya, serta menolak terikat kewajiban-kewajiban perkawinan.

\subsection{Tindakan}

Unsur kedua dari simulasi adalah tindakan (actus). Tindakan di sini merupakan perwujudan dari kehendak. Tidak cukup bahwa seseorang memiliki kehendak. Dalam simulasi, kehendak haruslah diwujudkan dalam tindakan, sehingga lahirlah apa yang dinamakan dengan "tindakan kehendak". Jadi kehendak, misalnya: untuk "tidak mau menikah dengan si A" haruslah diwujudkan ke dalam tindakan, sehingga lahirlah "tindakan kehendak" (actus voluntatis) "tidak mau menikah dengan si A". Dan "tindakan kehendak" ini seringkali didahului oleh motivasi

\footnotetext{
${ }^{8}$ Alf. Catur Raharso, Op. Cit., hlm. 253-254.

${ }^{9}$ Ibid., hlm. 254-256.
} 
luaran atau interese tertentu yang menjadi alasan untuk melakukan simulasi. Oleh karena itu dalam pembuktian perkara simulasi haruslah dibedakan antara: alasan untuk menikah (causa contrahendi), misalnya: menikah karena sudah hamil; dan alasan untuk melakukan simulasi (causa simulandi), misalnya berpura-pura menikah karena ingin memiliki harta warisan. ${ }^{10}$

\subsection{Positif}

Unsur pembentuk simulasi yang ketiga ialah sifat positif dari tindakan kehendak. Artinya tindakan kehendak itu harus bersifat positif (positivus). Maksudnya, tindakan kehendak itu harus diwujudkan atau dilaksanakan, sehingga dapat dibuktikan. Misalnya, beberapa hari setelah menikah, pelaku simulasi meninggalkan pasangannya dan tidak pernah kembali lagi. Jadi kehendak harus terjadi, atau sesuatu harus terjadi lewat kehendak itu. Dengan demikian, "tindakan kehendak" menjadi sesuatu yang objektif melalui pernyataan-pernyataan dan perilaku yang jelas. Sifat positif dari tindakan kehendak juga berarti bahwa kehendak melakukan simulasi harus bisa dibuktikan dalam tata lahir dan memungkinkan tercapainya kepastian moral mengenai fakta simulasi dalam tatanan yuridis intersubjektif atau ekstern. Kuatnya tindakan kehendak ditunjukkan dengan aspek imperatif dari kehendak itu sendiri. Dengan demikian, tindakan kehendak sungguh-sungguh merupakan pilihan dan keputusan seseorang terkait dengan objek tertentu, dengan diri sendiri dan dengan alasan-alasannya, sehingga antara diri orang itu dan tindakannya terdapat kesatuan yang aktual dan vital. ${ }^{11}$

\section{Bentuk-Bentuk Perwujudan Simulasi}

Perkawinan yang dilangsungkan dengan simulasi dari hakekatnya adalah perkawinan yang tidak sah, karena kesepakatan nikah atau konsensus yang diberikan dalam upacara perkawinan itu tidak memenuhi persyaratan sebagai kesepakatan untuk mendirikan perkawinan. Kanon 1101 $\S 2$ membedakan dua jenis simulasi, yakni simulasi total dan simulasi parsial.

\subsection{Simulasi Total (Simulatio Totalis Contra Matrimonium Ipsum)}

\subsubsection{Hakekat Simulasi Total}

Menurut Kan. $1055 \S 1$, perkawinan pada hakekatnya adalah persekutuan atau kebersamaan seluruh hidup antara seorang pria dan seorang wanita. Pria dan wanita yang melangsungkan perkawinan, namun pada saat yang sama menolak persekutuan hidup perkawinan, pada hakekatnya menolak perkawinan itu sendiri. Dengan itu perkawinan yang dilangsungkan adalah perkawinan yang tidak sah. Pengecualian perkawinan itu sendiri disebut simulasi total.

Simulasi total terjadi kalau pada saat perkawinan dilangsungkan, ada kehendak positif dalam hati untuk sama sekali tidak mau menikah, dengan secara mendasar menolak untuk menerima pihak lain sebagai suami atau sebagai istri dengan kehendak untuk melepaskan seluruh bentuk kewajiban, baik moral maupun hukum dari perkawinan yang dilangsungkan itu. Kehendak untuk mengecualikan perkawinan itu sendiri menyebabkan perkawinan yang dilaksanakan menjadi tidak sah. Dalam simulasi total, yang bersangkutan secara positif

${ }^{10}$ Fransiskus Homenara, Simulasi Sebagai Pokok Sengketa Dalam Perkara Pernyataan Pembatalan Perkawinan: Kursus Fungsionaris Tribunal Indonesia Timur: Weetebula, 2018, hlm. 3.

${ }^{11}$ Alf. Catur Raharso, Op. Cit., hlm. 258-259. 
berkehendak untuk menolak perkawinan itu sendiri dan secara sadar tidak mau menikah dan tidak mau menerima serta mengemban segala hak dan kewajiban yang merupakan konsekwensi yang melekat dengan perkawinan itu sendiri. ${ }^{12}$

Simulasi total adalah simulasi yang paling radikal. Kata "total" tidak berarti keseluruhan total dari unsur-unsur yang membentuk struktur esensiil dari perkawinan, melainkan prinsip utuh yang membentuk ikatan yuridis perkawinan. Ikatan nikah bukanlah suatu unsur yang sifatnya eksternal bagi kedua mempelai, bukan jembatan yang menghubungkan dua individu yang menikah, juga bukan sekumpulan hak dan kewajiban yang dikenakan pada kedua mempelai oleh otoritas publik; melainkan prinsip pemersatu yang lahir dari kedua mempelai untuk direalisasi melalui kesepakatan nikah. Seorang laki-laki dan seorang perempuan disebut suami istri sejauh mereka "bersatu dalam persekutuan suami istri", menjadi "satu daging", "bersatu dalam eksistensi dan kehidupan". 13

Dalam dan dengan kesepakatan nikah, suami dan istri saling memberi dan menerima diri pribadi sebagai pasangan; dan juga saling menyerahkan dan menerima sekumpulan hak dan kewajiban yang khas dan hakiki dari perkawinan, yang menuntut komitmen total atas dasar keadilan. Ikatan nikah dengan demikian mengandung tuntutan kesetaraan dan keadilan. Karena itu, jika salah satu atau keduanya dengan kehendak positif mengecualikan secara total unsur pemberian dan penerimaan diri atau relasi atas dasar keadilan, maka salah satu atau keduanya itu menikah secara tidak sah. Simulasi total di sini dimengerti sebagai tindakan mengeksklusi atau mengecualikan secara absolut semua hak dan kewajiban perkawinan. Karena itu harus ditegaskan bahwa simulasi total tidak berarti tidak adanya "kehendak untuk menikah" (intentio contrahendi), melainkan adanya "kehendak untuk tidak menikah" (intentio non contrahendi). ${ }^{14}$

Dalam simulasi total, pelaku simulasi memiliki 2 (dua) kehendak positif sekaligus, yakni pertama: kehendak untuk melaksanakan suatu "tindakan lahiriah" melalui kesepakatan nikah, yang memberi kesan kepada publik bahwa perkawinannya telah dilangsungkan; dan kedua: kehendak untuk mengeksklusi atau menolak sama sekali semua konsekwensi yang seharusnya dilaksanakan dan diemban karena perayaan perkawinan itu.

\subsubsection{Bentuk Perwujudan Simulasi Total}

Simulasi total sebagai tindakan positif kehendak yang mengecualikan perkawinan dapat muncul dalam berbagai bentuk perwujudan sebagai berikut. ${ }^{15}$

a) Simulasi total terjadi pada orang yang tidak mau tunduk pada ajaran resmi Gereja tentang perkawinan serta kewajiban yang harus diemban dalam lembaga perkawinan gerejawi karena mentalitas bebas yang menganggap perkawinan adalah urusan pribadi yang tidak harus terikat oleh tertib dan pengaturan disiplin gerejawi. Pelaku simulasi sebenarnya secara positif dalam batinnya tidak memiliki kehendak untuk memberikan kesepakatan nikah, ia hanya bersandiwara lewat ungkapan lahiriah, berpura-pura melangsungkan perkawinan.

\footnotetext{
${ }^{12}$ Moses Komela Avan, Op. Cit., hlm. 126.

13 Alf. Catur Raharso, Op. Cit., hlm. 260-261.

${ }^{14}$ Ibid., hlm. 261.

${ }^{15}$ Moses Komela Avan, Op. Cit., hlm. 127-128.
} 
b) Simulasi total terjadi ketika ada penolakan terhadap pasangan yang menjadi suami atau istri, misalnya karena dijodohkan atau dipaksakan untuk menikah. Pelaku simulasi menerima untuk melangsungkan perkawinan, namun dalam batinnya secara positif tidak menghendaki perkawinan yang dilangsungkan itu. Hal ini akan ditandai dengan penolakan untuk menjalani hidup bersama dengan pasangannya; serta penolakan untuk menerima dan mengemban segala kewajiban sebagaimana layaknya dalam sebuah perkawinan.

c) Simulasi total dapat terjadi ketika seseorang melangsungkan perkawinan, namun secara tegas berniat mengingkari hakikat perkawinan sebagai persekutuan hidup bersama yang diarahkan kepada kebaikan suami-istri serta kelahiran dan pendidikan anak-anak.

d) Simulasi total juga dapat terjadi ketika seseorang menikah, tetapi tujuan yang mau dicapai dari perkawinan yang dilangsungkan itu bukanlah tujuan yang khas dari perkawinan. Misalnya, seseorang melangsungkan perkawinan supaya mendapatkan pembantu tetap, dan karena itu menolak hakekat perkawinan sebagai persekutuan hidup bersama yang terarah kepada kebaikan suami-istri serta kelahiran dan pendidikan anakanak yang merupakan hasil dari kerja sama seksual.

e) Kanon $1055 \S 2$ menegaskan bahwa bagi orang-orang yang telah dibaptis, perkawinan adalah sakramen, yang berarti tidak terceraikan. Simulasi total terjadi ketika pria dan wanita yang terbaptis menikah, salah satu pihak atau keduanya mengecualikan martabat sakramental dari perkawinan. Pengecualian martabat sakramental dari perkawinan itu merupakan salah satu bentuk perwujudan dari pengecualian terhadap perkawinan itu sendiri.

\subsection{Simulasi Parsial atau Sebagian (Simulatio Partialis)}

\subsubsection{Hakekat Simulasi Parsial}

Simulasi parsial terjadi ketika seseorang menghendaki perkawinan atau melangsungkan perkawinan dengan memberikan kesepakatan nikah, namun sekaligus dengan kemauan positif dia mengecualikan sebagian dari perkawinan itu sendiri, yakni salah satu atau beberapa dari unsur hakiki perkawinan, atau salah satu atau beberapa dari sifat-sifat hakiki perkawinan.

Kanon $1055 \S 1$ menyebutkan dua unsur hakiki perkawinan, yakni: kesejahteraan suamiistri (bonum coniugum) serta kelahiran dan pendidikan anak (bonum prolis). Pengecualian terhadap salah satu unsur hakiki perkawinan pada hakekatnya merupakan sebuah simulasi parsial, karena pelaku simulasi menolak hanya salah satu bagian integral dari hakekat perkawinan. Pengecualian terhadap kesejahteraan suami-istri sebagai unsur hakiki perkawinan dinamakan "simulatio partialis contra bonum coniugum"; sedangkan pengecualian terhadap kelahiran dan pendidikan anak sebagai unsur hakiki perkawinan dinamakan "simulatio partialis contra bonum prolis". 16

Kanon 1056 mengatakan bahwa sifat-sifat (proprietas) hakiki perkawinan adalah unitas (kesatuan) dan indissolubilitas (sifat tak dapat diputuskan). Pengecualian terhadap salah satu sifat hakiki perkawinan pada hakekatnya merupakan sebuah simulasi parsial, karena pelaku

\footnotetext{
${ }^{16}$ Fransiskus Homenara, Op. Cit., hlm. 4.
} 
simulasi menolak hanya salah satu bagian integral dari hakekat perkawinan. Pengecualian terhadap kesatuan (unitas) sebagai sifat hakiki perkawinan dinamakan "simulatio partialis contra unitatem matrimonii" (contra bonum fidei); sedangkan pengecualian terhadap sifat tak dapat diputuskan (indissolubilitas) sebagai sifat hakiki perkawinan dinamakan "simulatio partialis contra indissolubilitatem matrimonii" (contra bonum sacramenti). ${ }^{17}$

Ketika seseorang menikah, seharusnya ia menghendaki pernikahan itu dengan semua unsur atau sifat-sifat hakiki perkawinan. Tetapi jika seseorang menikah, dan sekaligus dia menolak atau membuang salah satu, atau beberapa unsur dan sifat hakiki perkawinan, maka dia menikah secara tidak sah. Dengan kata lain, simulasi parsial terjadi ketika salah satu atau kedua belah pihak berkehendak untuk membangun persekutuan perkawinan dengan pasangannya, namun serentak menolak atau menyangkal (mengeksklusi) secara positif salah satu atau beberapa unsur dan salah satu atau beberapa sifat hakiki dari perkawinan.

\subsubsection{Simulatio Partialis Contra Bonum Coniugum}

\subsubsection{Hakekat Bonum Coniugum}

Bonum coniugum adalah sesuatu yang baik dan bernilai, yakni sebuah nilai etis yang saling diberikan dan diterima oleh suami istri. Suami istri berupaya secara aktif dan kreatif tidak hanya untuk menyelenggarakan apa yang baik dalam kehidupan keluarga mereka, melainkan semua yang menjadikan mereka sebagai suami istri, "baik" keadaannya (bonum). Suami istri menumbuhkembangkan kebaikan secara timbal balik, tanpa masing-masing memikirkan keuntungan diri sendiri. Dalam upaya untuk mendatangkan apa yang baik bagi pasangan, suami istri harus memandang dan memperlakukan pasangannya sebagai pribadi (bonum harus bersifat personal). Artinya, suami istri harus mencari dan menemukan apa yang baik bagi diri dan bagi pasangannya dalam kehidupan perkawinan bersama pasangannya. Dan ketika salah satu pihak mengupayakan kebaikan bagi pasangannya, hal itu harus merupakan ungkapan pemberian dirinya. $^{18}$

Selain bersifat baik karena bernilai, dan personal, bonum coniugum juga bersifat interpersonal dan conjugal. Dalam mengupayakan dan mewujudkan apa yang baik dalam kehidupan perkawinan, suami istri tidak boleh melakukannya secara sendiri-sendiri, melainkan bersama-sama sebagai pasangan, dan upaya pemberian apa yang baik bagi pasangan itu dilaksanakan secara timbal balik (interpersonal). Suami istri membangun kebersamaan hidup dalam setiap situasi (kondisi apapun) dan selalu mengupayakan persekutuan dalam setiap karya atau tindakan mereka. Dan yang terakhir, bonum itu sendiri harus bersifat conjugal, artinya khas bagi suami istri yang hidup dalam perkawinan, dalam rangka mencapai semua tujuan dan ciri hakiki perkawinan. Bonum atau kebaikan yang diupayakan bukan hanya untuk pribadi pasangan secara individual, melainkan untuk dan demi pasangan berdua sebagai suami istri (bonum coniugum), serta dalam upaya membangun persekutuan (kebersamaan) dan persahabatan. Dalam membangun hidup perkawinan dan keluarga, suami istri melaksanakan keterlibatan secara bersama-sama dan timbal baik dalam memberi dan menerima apa yang baik (bonum) demi menegakkan persekutuan perkawinan. ${ }^{19}$

\footnotetext{
${ }^{17}$ Ibid., hlm. 4-5.

${ }^{18}$ Alf. Catur Raharso, Op. Cit., hlm. 294.

${ }^{19}$ Ibid., hlm. 295.
} 
Selain memiliki sifat-sifat seperti dikatakan di atas, ada elemen-elemen penting yang melekat dengan kata bonum coniugum itu sendiri. Elemen-elemen yang dimaksud ialah: pertama, persekutuan. Perkawinan dipandang sebagai persekutuan personal atau persatuan pribadi-pribadi di mana suami istri sepakat untuk hidup bersama dan berjanji untuk saling menguntungkan dalam hidup bersama. Kedua, perbuatan baik atau kebajikan. Perkawinan dipandang sebagai sebuah relasi interpersonal yang mendalam dan intens antara suami-isteri. Perbuatan baik yang dimaksud ialah kemauan dan tindakan untuk melakukan sesuatu yang baik bagi pasangan. Ketiga, pendampingan. Codex 1917 memandang perkawinan sebagai kesatuan ranjang, meja, dan tempat tinggal. Sedangkan Codex 1983 mengartikan perkawinan sebagai kebersamaan seluruh hidup. Pendampingan yang dimaksud adalah usaha suami istri untuk saling berbagi diri dan hidup (pikiran dan perasaan, baik secara eksternal maupun internal) satu terhadap yang lain dalam lembaga perkawinan. Keempat, persahabatan. Relasi yang dibangun oleh suami istri harus berlandas pada kehendak agar pasangan mengalami kebaikan, kehidupan, rasa senang, dan merasa senasib sepenangggungan. Kelima, Kepedulian. Kepedulian yang dimaksud adalah perhatian penuh tanggungjawab terhadap pasangan dengan menolongnya supaya dia bertumbuh dan berkembang. Dalam relasi suami istri, kepedulian satu terhadap yang lain harus disertai dengan keterbukaan untuk menerima kepedulian pasangan hidup. Dan keenam, cinta atau kasih sayang. Dalam konteks perkawinan, kata cinta secara khusus dipahami sebagai sebuah tendensi afektif yang secara kodrati bersifat dialogal terhadap seorang pribadi yang lain dan terarah pada kesatuan dengannya. ${ }^{20}$

\subsubsection{Hakekat Simulatio Partialis Contra Bonum Coniugum}

Pada prinsipnya "simulatio partialis contra bonum coniugum" terjadi ketika seseorang melangsungkan perkawinan dengan memberikan kesepakatan nikah namun dalam kehendak bebas di dalam hatinya secara positif mengecualikan kesejahteraan atau kebahagiaan suami istri sebagai unsur hakiki perkawinan. Kehendak untuk mengecualikan kesejahteraan atau kebahagiaan suami istri sebagai unsur hakiki perkawinan itulah yang menyebabkan perkawinan yang dilaksanakan menjadi tidak sah dan karena itu dapat dinyatakan batal oleh Tribunal Gerejawi.

Pengecualian terhadap kesejahteraan atau kebahagiaan suami-istri sebagai unsur hakiki perkawinan terjadi ketika ada penolakan terhadap nilai-nilai kebahagiaan suami istri dari perkawinan tersebut. Simulator menerima untuk melangsungkan perkawinan, namun dalam batinnya secara positif dia tidak menghendaki kesejahteraan atau kebahagiaan suam istri. Hal itu dapat ditunjukkan oleh pelaku simulasi, misalnya selama masa pacaran, masa pertunanganan dan hidup perkawinan, dia selalu menolak untuk melakukan kebaikan (bonum) kepada pasangannya.

\subsubsection{Contoh Kasus Simulatio Partialis Contra Bonum Coniugum}

Salah satu pasangan secara permanen mengecualikan hak untuk hidup dan tinggal bersama. Tinggal dan hidup bersama merupakan salah satu faktor yang dapat mendukung kesejahteraan hidup suami istri. Kendati demikian, kesejahteraan suami istri juga dapat terwujud tanpa tinggal dan hidup bersama. Misalnya dalam kasus suami istri yang tinggal terpisah oleh karena kerja, tugas belajar, dipenjara dan sebagainya. Dalam ajaran kanonik, tinggal bersama memang tidak dipandang sebagai unsur esensiil dari perkawinan, namun tetap dianggap sebagai bagian integral dari perkawinan. Perkawinan tetap ada, dan tetap bisa membawa kesejahteraan bagi suami istri

${ }^{20}$ I Gusti Bagus Kusumawanta, Op. Cit., hlm. 214-217. 
kendati mereka tidak tinggal bersama. Namun, bila dengan kehendak positif dan secara permanen seseorang menolak tinggal dan hidup bersama sebagai suami istri dengan pasangannya, maka hal itu dapat dinyatakan bahwa secara implisit seseorang mengeksklusi atau mengecualikan hak atas pasangan hidup dan perkawinan itu sendiri; dan hal ini dapat dikatakan dia melakukan simulasi total. Karena itu kita perlu menyadari secara fundamental perbedaan antara tidak adanya kohabitasi (tinggal bersama sebagai suami istri) karena alasan-alasan yang wajar dan masuk akal (seperti karena kerja, tugas belajar atau dipenjara), dengan kehendak positif sebelum menikah untuk menolak hak tinggal bersama dengan pasangan. Jika tidak adanya kohabitasi itu terjadi karena adanya kehendak positif sejak awal dari simulator, maka dia melakukan simulasi atau eksklusi bonum coniugum. ${ }^{21}$

\subsubsection{Simulatio Partialis Contra Bonum Prolis}

Kanon 1055 \& 1 menyebutkan bahwa unsur-unsur hakiki dari perkawinan ialah kesejahteraan suami istri serta kelahiran dan pendidikan anak. Dari ketentuan kanon ini kita mendapatkan keterangan bahwa kelahiran dan pendidikan anak merupakan salah satu unsur hakiki dari perkawinan. Frase "kelahiran dan pendidikan anak" menunjuk pada "makna prokreatif" perkawinan yang biasa dikenal dengan bonum prolis.

Bonum prolis sebagai salah satu unsur hakiki perkawinan mengacu pada makna prokreatif perkawinan, baik secara kuantitatif (kelahiran anak) maupun secara kualitatif (pendidikan anak). Pada hakekatnya bonum prolis sangat berpautan erat dengan persekutuan suami istri (persetubuhan) yang merupakan aktivitas seksual suami istri yang memungkinkan tercapainya makna prokreatif dari perkawinan (baik secara kuantitatif maupun secara kualitatif). Karena itu dapatlah dikatakan bahwa "hak atas persetubuhan" merupakan hakekat dari bonum prolis. ${ }^{22}$

Hak atas persetubuhan sebagai hakekat dari bonum prolis harus terwujud dalam elemenelemen integral berikut. Pertama: Hak atas persetubuhan. Suami-istri yang menikah, secara kodrati berhak untuk melakukan persetubuhan dengan pasangannya. Pelaksanaan hak atas persetubuhan tersebut harus diwujudkan secara manusiawi. Kedua: Hak atas persetubuhan yang terarah atau terbuka kepada kehamilan. Suami istri yang menikah, secara kodrati berhak untuk melakukan persetubuhan dengan pasangannya, yang terarah pada proses pembuahan atau kehamilan. Ketiga: Hak atas kelahiran anak. Suami istri yang menikah, secara kodrati berhak atas kelahiran anak yang merupakan hasil dari kehamilan karena persetubuhan dengan pasangannya. Keempat: Hak atas pendidikan anak. Suami istri yang menikah, secara kodrati berhak atas pendidikan anak yang lahir dalam perkawinan mereka; meliputi pendidikan fisik, sosial, kultural, moral, dan religius. ${ }^{23}$

Pada prinsipnya simulatio partialis contra bonum prolis terjadi ketika seseorang melangsungkan perkawinan dengan memberikan kesepakatan nikah, namun dalam kehendak bebas di dalam hatinya secara positif dia mengecualikan makna prokreatif, yakni kelahiran dan pendidikan anak sebagai unsur hakiki dari perkawinan. Kehendak untuk mengecualikan makna prokreatif sebagai unsur hakiki perkawinan itulah yang menyebabkan perkawinan yang dilaksanakan menjadi tidak sah dan karena itu dapat dinyatakan batal oleh Tribunal Gerejawi. Jadi, ketika seseorang menolak hak atas persetubuhan, menolak kemungkinan untuk terjadinya

\footnotetext{
${ }^{21}$ Alf. Catur Raharso, Op. Cit., hlm. 300.

${ }^{22}$ Fransiskus Homenara, Op. Cit., hlm. 18.

${ }^{23}$ Ibid.
} 
kehamilan, menolak akan datangnya anak atau akan adanya kelahiran, serta menolak untuk memberikan pendidikan kepada anak, maka dia melakukan simulatio partialis contra bonum prolis.

\subsubsection{Simulatio Partialis Contra Bonum Fidei}

Kanon 1056 menyebutkan bahwa ciri-ciri hakiki (proprietates) perkawinan ialah unitas (kesatuan) dan indissolubilitas (sifat tak dapat diputuskan), yang dalam perkawinan kristiani memperoleh kekukuhan khusus atas dasar sakramen. Dari kanon ini terlihat jelas bahwa ada 2 hal yang menjadi unsur hakiki dari perkawinan, yakni kesatuan (unitas) dan sifat tak dapat diputuskan (indissolubilitas). Pembahasan bagian ini dikhususkan pada kesatuan (unitas) sebagai salah satu unsur hakiki perkawinan.

Kesatuan atau unitas menunjuk pada sifat unitif dan monogam dari perkawinan. Perkawinan memiliki sifat unitif, artinya perkawinan itu menyatukan pria dan wanita yang menjadi suami istri. Persatuan yang dimaksud ialah persatuan secara lahir dan batin. Perkawinan juga bersifat monogam, maksudnya perkawinan itu dinyatakan sah jika dilaksanakan hanya antara seorang pria dan seorang wanita. Karena itu, dalam perkawinan katolik tidak diperkenankan dan tidak dibenarkan adanya poligami (seseorang memiliki suami atau istri lebih dari satu orang). Sifat monogam yang dianut serentak menolak adanya poligini (seorang suami mempunyai istri lebih dari satu orang), dan menolak adanya poliandri (seorang istri mempunyai suami lebih dari satu orang). Sifat hakiki unitif dan monogam perkawinan ini biasa disebut juga dengan bonum fidei.

Kata bonum fidei dipahami sebagai "makna kesetiaan perkawinan". Dalam arti luas bonum fidei berarti "kepercayaan, loyalitas dan dukungan yang ditunjukkan secara timbal balik oleh pasangan nikah satu terhadap yang lain". Jadi istilah bonum fidei menunjuk pada "hak atas kesetiaan" dalam perkawinan. Secara yuridis, istilah bonum fidei mengacu pada "kemenetapan relasi seksual pada satu partner hidup". Jadi dalam arti sempit istilah bonum fidei menunjuk pada "hak atas kesatuan" dalam perkawinan. Karena itu dapatlah dikatakan bahwa hakekat dari bonum fidei adalah "hak atas kesetiaan" dan "hak atas kesatuan"dalam perkawinan. ${ }^{24}$

Secara yuridis, kesetiaan tidaklah identik dengan unitas. Pemahaman yuridis yang lebih luas memasukkan beberapa unsur hakiki yang mendukung kesetiaan perkawinan yakni kepercayaan, loyalitas, dan sikap saling mendukung. Sementara secara sempit, kesetiaan perkawinan lebih mengacu kepada kesetiaan secara seksual, yakni komitmen untuk melakukan hubungan seks hanya dengan pasangan perkawinan. Kesetiaan di sini memberikan penegasan bahwa suami dan istri kehilangan hak untuk memiliki pasangan lain, baik yang sifatnya sementara maupun permanen. Suami istri kehilangan hak untuk berpoligami dan atau berselingkuh (bdk. Kan.1134). Hak atas kesetiaan mengecualikan atau mengesampingkan hak pasangan untuk menjalin hubungan seks dengan orang lain, entah dengan lawan jenis maupun sama jenis. ${ }^{25}$

Unitas menuntut hanya satu ikatan perkawinan yang sah (kanon 1056). Sedangkan kesetiaan menuntut tidak hanya satu ikatan perkawinan yang sah, melainkan juga hak dan kewajiban timbal balik untuk membangun relasi seksual suami istri secara eksklusif. Kesetiaan

\footnotetext{
${ }^{24}$ Ibid., hlm. 23.
}

${ }^{25}$ I Gusti Bagus Kusumawanta, Op. Cit., hlm. 66. 
suami istri menuntut tidak hanya kesatuan lembaga perkawinan, melainkan juga kesatuan personal, komunio eksklusif dari cinta kasih suami istri. Jadi, kesetiaan tidak identik dengan unitas, namun memiliki kaitan dan bahkan merupakan bagian dari ikatan perkawinan yang satu, eksklusif, total, dan interpersonal. ${ }^{26}$

Yurisprudensi lama mereduksi dan mengembalikan kesetiaan kepada kesatuan. Sedangkan yurisprudensi modern meluaskan arti kesatuan dengan memasukkan pengertian kesetiaan di dalamnya. Di dalam perkawinan, masing-masing pihak memiliki hak radikal atas relasi yang setia dan eksklusif dari, dengan, dan terhadap pasangannya. Kedua pihak sama-sama harus memiliki kehendak untuk membangun relasi semacam itu dan selalu mengupayakan perwujudannya dalam kehidupan perkawinan. Kesetiaan (fidelitas) dalam relasi suami istri merupakan kesejahteraan dan kebaikan bersama milik pasangan itu sendiri secara eksklusif. Pengecualian atau penolakan terhadap kesetiaan relasi suami istri, membuat perkawinan tersebut tidak sah sejak awal. ${ }^{27}$

Pokok persoalan tentang simulasi terhadap sifat kesatuan (unitas) perkawinan bermula dari tafsir atas Kan. 1081- $§ 2$ dari Kitab Hukum Kanonik 1917 yang merumuskan tujuan perkawinan sebagai "hak kekal dan penuh atas tubuh (ius in corpus) yang terarah kepada perbuatan yang dari kodratnya tertuju kepada kelahiran anak". Dengan dasar rumusan ini dapat ditegaskan bahwa melakukan persetubuhan dengan orang lain yang bukan suami dan bukan istri (yang dari kodratnya terarah kepada kelahiran anak) adalah pelanggaran atas hak kekal dan eksklusif atas tubuh yang harus diberikan hanya kepada pasangan sendiri. ${ }^{28}$

Simulatio partialis contra bonum fidei atau simulatio partialis contra unitatem matrimonii terjadi ketika salah satu pihak atau kedua belah pihak melangsungkan perkawinan tetapi dari kehendak positifnya mengecualikan unitas atau monogam sebagai sifat hakiki perkawinan, yang meliputi "penolakan hak atas kesetiaan dan hak atas kesatuan perkawinan". Pada hakekatnya simulatio partialis contra unitatem matrimonii dalam arti luas berarti adanya kehendak positif untuk "menolak sikap saling percaya, saling setia dan saling mendukung antar pasangan yang menikah". Dan dalam arti sempit berarti adanya kehendak positif untuk "menolak ekslusivitas relasi seksual antara satu suami-satu istri dalam ikatan perkawinan" dengan berkehendak memberikan hak itu kepada orang lain di luar perkawinan.

Menurut doktrin kanonik pada umumnya dan yurisprudensi, pengecualian atau penolakan terhadap kesetiaan relasi suami istri (simulatio partialis contra bonum fidei) dapat terwujud antara lain dengan: a) kehendak dan rencana untuk berzinah (ius adulterandi); b) kehendak dan rencana untuk mempraktekkan relasi seksual yang melawan kodrat (contra naturam) dengan orang lain yang bukan suami dan bukan istri sendiri, entah itu berupa relasi heteroseksual ataupun homoseksual; c) kehendak dan rencana untuk memiliki relasi intim bercorak sentimental, afektif dan cinta, yang memang merupakan inklinasi seksual khas pria dan wanita, meskipun tidak dibarengi dengan persetubuhan seksual. ${ }^{29}$

\footnotetext{
${ }^{26}$ Ibid., hlm. 69.

${ }^{27}$ Ibid., hlm. 70.

${ }^{28}$ Moses Komela Avan, Op. Cit., hlm. 145.

${ }^{29}$ I Gusti Bagus Kusumawanta, Op. Cit., hlm. 70.
} 


\subsubsection{Simulatio Partialis Contra Bonum Sacramenti}

Kanon 1056 menyebutkan bahwa selain kesatuan (unitas), sifat tak dapat diputuskan (indissolubilitas) adalah salah satu ciri hakiki (proprietates) perkawinan. Ciri atau sifat hakiki perkawinan yang tidak dapat diputuskan ini biasa disebut dengan bonum sacramenti. Kitab Hukum Kanonik 1983, khususnya Kann. 1055 § 1, 1056, 1057 §, dan 1134 menegaskan bahwa bonum sacramenti merupakan salah sifat hakiki perkawinan. Karena itu, kata bonum sacramenti dipahami sebagai "kesatuan erat yang tak-terputuskan" antara seorang pria dan seorang wanita yang menikah. Hal itu berarti "orang-orang yang menikah memiliki hak untuk saling menerima dan saling memberi dalam persekutuan eksklusif seumur hidup".

Menurut Bapa-bapa Konsili Vatikan II, pada hakekatnya "kekalnya relasi suami istri" bukan hanya diperuntukkan bagi perkawinan kristiani, tetapi secara kodrati berdasarkan kehendak Allah, diperuntukkan bagi semua lembaga perkawinan (bdk. GS, 48). "Persekutuan tetap" antara suami istri diikat oleh perjanjian yang tak dapat ditarik kembali. Hal ini berarti persekutuan hidup suami istri dalam perkawinan tidak bersifat temporal, atau untuk suatu masa waktu tertentu. Waktunya tidak dibatasi. Perkawinan itu berlangsung seumur hidup mempelai. Dan secara yuridis, hanya kematianlah yang mengakhiri ikatan perkawinan suami istri. ${ }^{30}$ Dengan demikian dapatlah ditegaskan bahwa "keterikatan tertutup seumur hidup antara seorang pria dan seorang wanita yang menikah" merupakan hakekat dari bonum sacramenti.

Simulatio partialis contra bonum sacramenti atau simulatio partialis contra indissolubilitatem matrimonii terjadi ketika salah satu pihak atau kedua belah pihak melangsungkan perkawinan, tetapi dari kehendaknya mengecualikan perkawinan mereka dari "keterikatan tertutup seumur hidup". Dalam diri orang-orang yang menikah "adanya kehendak positif untuk sekali waktu mengakhiri relasi perkawinan mereka dengan menceraikan pasangannya". Dengan kata lain berarti adanya kehendak positif untuk menolak kemenetapan relasi seumur hidup antara satu suami-satu istri dalam ikatan perkawinan, dan berkehendak mengakhiri relasi tersebut dengan alasan apa pun. Pengecualian sifat tidak terputuskan ikatan perkawinan (indissolubilitas/bonum sacramenti) sebagai sifat hakiki perkawinan dengan "kehendak positif" diwujudkan dalam pelbagai bentuk dan diungkapkan baik secara eksplisit atau terbuka maupun secara implisit atau terselubung oleh simulator. ${ }^{31}$

Bagaimana perwujudan simulatio partialis contra bonum sacramenti atau simulatio partialis contra indissolubilitatem matrimonii? Pada hakekatnya pengecualian indissolubilitas sebagai sifat hakiki perkawinan tidak selalu berdiri sendiri, tetapi selalu berkaitan dengan simulatio partialis contra bonum prolis atau simulatio partialis contra unitatem matrimonii. Karena itu sangat dibutuhkan kejelian dalam memantau kompleksitas realitas simulatio partialis contra indissolubilitatem matrimonii. Pengecualian bonum prolis sering didorong oleh kehendak positif untuk mengecualikan indissolubilitas perkawinan. Seseorang mengecualikan bonum prolis karena berkehendak untuk sekali waktu dengan mudah mengakhiri ikatan perkawinan dengan pasangannya tanpa harus repot memikirkan tanggungjawabnya terhadap anak-anaknya. Orang tersebut pada hakekatnya mengecualikan indissolubilitas perkawinan. Demikian juga pengecualian unitas perkawinan sering didorong oleh kehendak positif untuk mengecualikan indissolubilitas perkawinan. Seseorang mengecualikan unitas perkawinan karena berkehendak untuk sekali waktu dengan mudah mengakhiri ikatan perkawinan dengan pasangannya karena

\footnotetext{
${ }^{30}$ Moses Komela Avan, Op. Cit., hlm. 138.

${ }^{31}$ Ibid.
} 
orang tersebut mempunyai "cadangan pasangan hidup yang lain". Orang tersebut pada hakekatnya mengecualikan indissolubilitas perkawinan. ${ }^{32}$

Simulator dalam simulasi parsial ini menolak pandangan Gereja tentang perkawinan sebagai yang bersifat tak terputuskan, sehingga pelaku tidak merasa wajib untuk melaksanakan persekutuan eksklusif seumur hidup dengan pasangannya. Pelaku simulasi parsial ini juga tidak menghendaki perkawinan gerejani yang sakramental, tetapi menginginkan bentuk ikatan perkawinan lain yang sekali waktu bisa saja dengan mudah diakhiri.

\section{PENUTUP}

Konsensus atau kesepakatan perkawinan dapat cacat atau tidak ada jika ditemukan adanya simulasi atau kepura-puraan. Simulasi berarti adanya ketidaksesuaian antara kata-kata atau isyarat yang dinyatakan dalam merayakan perkawinan dengan kesepakatan batin dalam hati. Unsur-unsur pembentuk simulasi ialah kehendak (voluntas), tindakan (actus), dan positif (positivus).

Ada simulasi total (simulatio totalis contra matrimonium ipsum) yaitu pengecualian terhadap perkawinan itu sendiri, dan simulasi sebagian (simulatio partialis). Simulasi sebagian terdiri dari: simulatio partialis contra bonum coniugum yaitu pengecualian terhadap kesejahteraan suami-istri sebagai unsur hakiki perkawinan; simulatio partialis contra bonum prolis yaitu pengecualian terhadap kelahiran dan pendidikan anak sebagai unsur hakiki perkawinan; simulatio partialis contra unitatem matrimonii atau simulatio partialis contra bonum fidei yaitu pengecualian terhadap kesatuan (unitas) sebagai sifat hakiki perkawinan; serta simulatio partialis contra indissolubilitatem matrimonii atau simulatio partialis contra bonum sacramenti yaitu pengecualian terhadap sifat tak dapat diputuskan (indissolubilitas) sebagai sifat hakiki perkawinan.

Simulasi terjadi ketika salah satu pihak atau kedua belah pihak dengan positif kemauannya mengecualikan perkawinan itu sendiri, atau salah satu unsur hakiki perkawinan, atau salah satu sifat hakiki perkawinan pada saat perkawinan dilangsungkan. Dan adanya simulasi (kepurapuraan menikah) dapat menjadi dasar untuk pembatalan perkawinan melalui Tribunal Gerejawi.

\footnotetext{
${ }^{32}$ Fransiskus Homenara, Op. Cit., hlm. 29.
} 


\section{Daftar Pustaka}

Catur Raharso, Alf. 2008.Kesepakatan Nikah Dalam Hukum Perkawinan Katolik, Malang: Dioma

Homenara, Fransiskus. 2018. Simulasi Sebagai Pokok Sengketa Dalam Perkara Pernyataan Pembatalan Perkawinan, Kursus Fungsionaris Tribunal Indonesia Timur: Weetebula

Kitab Hukum Kanonik 1983: Edisi Resmi Bahasa Indonesia: Jakarta: KWI, 2006.

Komela Avan, Moses. 2014. Kebatalan Perkawinan, Pelayanan Hukum Gereja Dalam Proses Menyatakan Kebatalan Perkawinan, Yogyakarta: Kanisius

Kusumawanta, I Gusti Bagus. 2019. Yurisprudensi Hukum Kanonik, Yogyakarta: Alinea Baru

Putusan Tribunal Perkawinan KAE (2018-2020).

Wea S. Turu, Don, Pencerahan Yuridis, 2014. Problematika dan Pemecahan Berdasarkan Kitab Hukum Kanonik 1983, Yogyakarta: Bajawa Press

Yosef Bria, Benyamin. 2007.Pastoral Perkawinan Gereja Katolik Menurut Kitab Hukum Kanonik 1983 Kajian dan Penerapannya, Yogyakarta: Yayasan Pustaka Nusatama 